

\section{FASHIONING GOTHIC BODIES}




\section{For Christine}

and Derek Spooner 


\section{Fashioning Gothic bodies}

Catherine Spooner

Manchester University Press

Manchester 
Copyright () Catherine Spooner 2004

The right of Catherine Spooner to be identified as the author of this work has been asserted by her in accordance with the Copyright, Designs and Patents Act 1988.

Published by Manchester University Press

Altrincham Street, Manchester M1 7JA, UK

www.manchesteruniversitypress.co.uk

British Library Cataloguing-in-Publication Data

A catalogue record for this book is available from the British Library

Library of Congress Cataloging-in-Publication Data

A catalog record for this book is available from the Library of Congress

ISBN 9780719064005 hardback

ISBN 9780719064012 paperback

ISBN 9781526125590 Institutional

First published by Manchester University Press 2004

First digital paperback edition published 2012

The publisher has no responsibility for the persistence or accuracy of URLs for any external or third-party internet websites referred to in this book, and does not guarantee that any content on such websites is, or will remain, accurate or appropriate. 